\title{
A high frequency time series at Weathership $M$, Norwegian Sea, during the 1997 spring bloom: the reproductive biology of Calanus finmarchicus
}

\author{
Barbara Niehoff ${ }^{1, *}$, Ulrike Klenke ${ }^{1}$, Hans-Jürgen Hirche ${ }^{1}$, Xabier Irigoien ${ }^{2}$, \\ Robert Head $^{2}$, Roger Harris ${ }^{2}$
}

\author{
${ }^{1}$ Alfred Wegener Institute for Polar and Marine Research, D-27568 Bremerhaven, Germany \\ ${ }^{2}$ Plymouth Marine Laboratory, Prospect Place, Plymouth PL1 3DH, United Kingdom
}

\begin{abstract}
The reproductive biology of Calanus finmarchicus was investigated at a permanent station in the Norwegian Sea (Weathership $\operatorname{Stn} M, 66^{\circ} \mathrm{N}, 2^{\circ} \mathrm{E}$ ) during a time series between March and June 1997 The temporal development of female abundance, egg production rate and gonad development stage in relation to the phytoplankton production cycle is described. Abundance of females, copepodite stage 5 and males as well as female gonad morphology were examined from WP2 net samples taken daily from the upper $100 \mathrm{~m}$. Daily egg production rate and number of spawning females were determined from 50 individual females placed in multiwells or beakers. Once a week a multinet haul from 1000-500-250-100-50-0 $\mathrm{m}$ was performed to study the depth distribution of females and gonad development stages. Results show that the reproductive period of $C$. finmarchicus in the Atlantic region of the Norwegian Sea can be subdivided in 3 periods in relation to phytoplankton development: (1) During the prebloom over a period of $49 \mathrm{~d}$ mean egg production rate was 8 eggs female $\mathrm{e}^{-1} \mathrm{~d}^{-1}$ and an average of $47 \%$ of the females were mature. (2) Coincident with the bloom in mid May the egg production rate increased up to a maximum of 44 eggs female $e^{-1} \mathrm{~d}^{-1}$ while more than $80 \%$ of the females were mature. (3) After the bloom at the beginning of June, egg production decreased, and mature females were only rarely found. Feeding experiments indicate that food quantity limited egg production prior to the bloom, while presumably food quality was not sufficient during postbloom. However, due to high female abundance the total population egg production prior to the bloom was the same as during the bloom. This implies that the reproduction of $C$. finmarchicus in the Norwegian Sea is to some extent decoupled from the phytoplankton bloom.
\end{abstract}

KEY WORDS: Calanus finmarchicus Norwegian Sea - Egg production Gonad development Phytoplankton

\section{INTRODUCTION}

Calanus finmarchicus is one of the key species in northern pelagic ecosystems. Detailed knowledge of its life cycle is essential for understanding the population dynamics and quantifying its role in the Norwegian Sea, one of the main centres of distribution (Skjoldal \& Rey 1989). Gonad maturation and egg production rate are key parameters for studying reproductive strategy, which plays an important role in adaptation to highly variable environments. Also, the use of

-E-mail: bniehoff@awi-bremerhaven.de egg production rates of herbivorous copepods as a measure of community secondary production has been discussed (McLaren \& Leonard 1995, Poulet et al. 1995). Despite its significance there is still a lack of knowledge of the environmental factors controlling reproduction. Several time series focusing on reproductive activity and environmental conditions have been carried out since the initial work of Marshall \& Orr (1953) in the Tromsø Sound, Norway, but samples were taken in weekly or biweekly intervals. This sampling frequency does not permit the assessment of short-term changes in reproduction as reproductive activity responds within 2 to $3 \mathrm{~d}$ to changes in ambient 
conditions such as temperature or food supply (Hirche et al. 1997). Moreover, previous time series were conducted in coastal areas (Sea of Clyde, UK, Marshall \& Orr 1955; lower estuary of the Gulf of St. Lawrence, Canada, Plourde \& Runge 1993) or in North Norwegian fjords (Tromsø Sound, Marshall \& Orr 1953; Balsfjord, Tande 1982; Malangenfjord, Diel \& Tande 1992). In such locations, reproduction and development of a new generation of $C$. finmarchicus is closely related to the phytoplankton bloom (Diel \& Tande 1992, Runge \& Plourde 1996). In the absence of phytoplankton $C$. finmarchicus is also capable of maintaining egg production based on microzooplankton feeding as shown by Ohman \& Runge (1994) in the Gulf of St. Lawrence. Information from the open ocean is scarce and available only from sporadic measurements (e.g. Greenland Sea, Hirche 1990; Fram Strait, Smith 1990; Norwegian Sea, Hirche et al. 1997) or derived from the occurrence of nauplii and eggs (Østvedt 1955 , Skjoldal et al. 1987). To fill this gap, we present here a study of the reproduction of $C$. finmarchicus performed in the Norwegian Sea including field observations and laboratory experiments. The goals of this study were (1) to investigate gonad development and to determine the timing of spawning and the magnitude of egg production at the open sea Weathership Stn Mike, (2) to relate reproduction to phytoplankton development, and (3) to compare the reproductive cycle of $C$. finmarchicus in the open ocean with that in coastal areas and fjords.

\section{MATERIAL AND METHODS}

Sampling. The time series was conducted from 22 March to 9 June 1997, at the Weathership Stn Mike $(\operatorname{Stn} M)$ in the Norwegian Sea $\left(66^{\circ} \mathrm{N}, 2^{\circ} \mathrm{E}\right)$. Due to drifting, samples were taken in an area of about 20 nautical miles in diameter (Fig. 1), mainly between 2000 and $2500 \mathrm{~m}$ bottom depth. During the whole investigation period of $80 \mathrm{~d}$ no samples were taken on 17 days due to bad weather conditions or due to monthly port calls

Two vertical hauls with a WP2 net (mesh size $50 \mu \mathrm{m}$ ) from the upper $100 \mathrm{~m}$ were taken daily at about 10:00 h. One haul was fixed in $4 \%$ formalin buffered with hexamethylentetramin for determination of abundance and gonad development stage. From these samples copepodite stage $\mathrm{V}(\mathrm{CV})$, males and females were sorted. From the second haul, live females were sorted immediately for egg production experiments. Once a week a vertical multinet (Hydrobios, Kiel; mesh size $150 \mu \mathrm{m}$ ) haul in depth intervals from $1000-500 \mathrm{~m}$, $500-250 \mathrm{~m}, 250-100 \mathrm{~m}, 100-50 \mathrm{~m}$ and $50-0 \mathrm{~m}$ was conducted to study the depth distribution of females

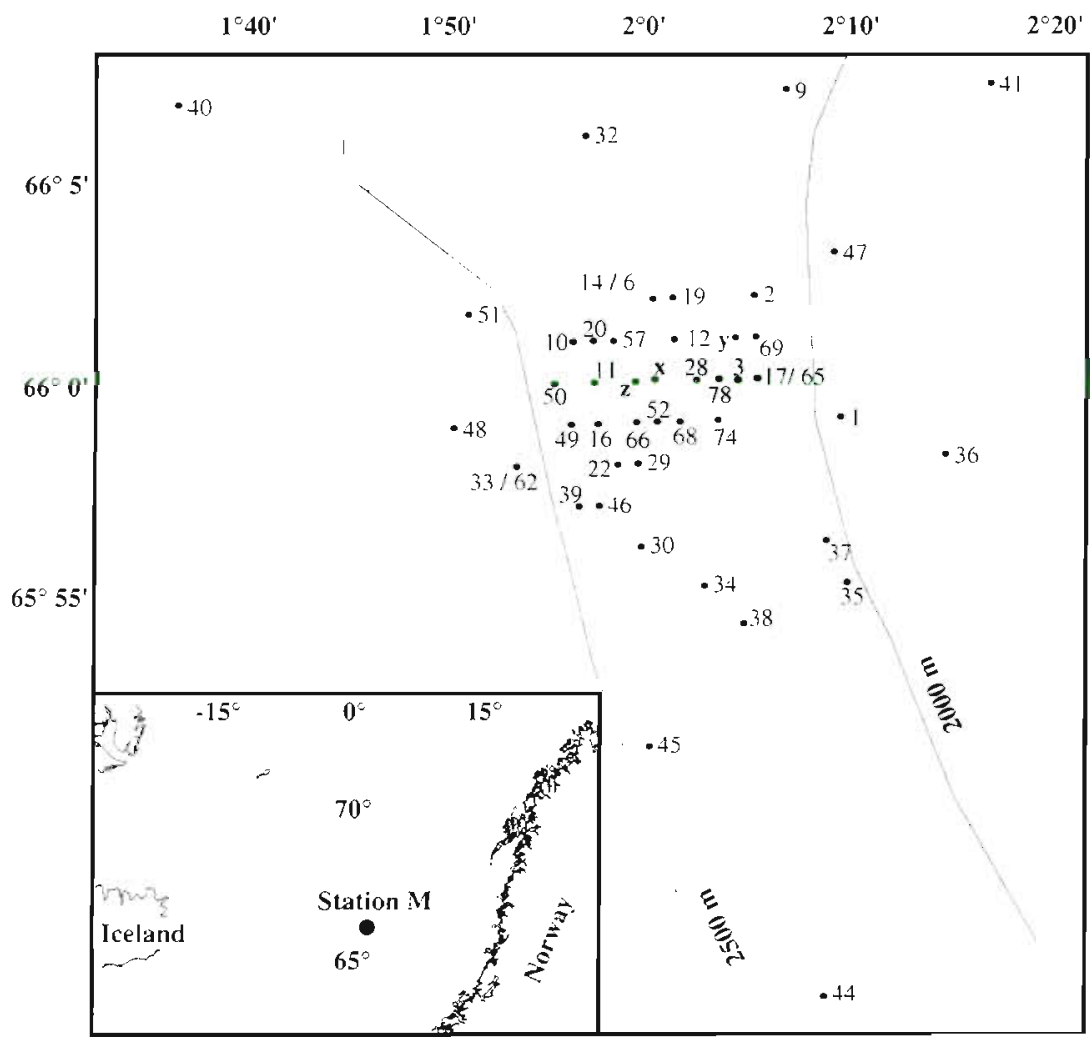

Fig. 1. Study area of the time series at Stn $M$ in 1997. (Inset map: overview of study area with position of Stn $M$.) Numbers indicate day of sampling, from Days 1. (March 22) to 80; several samples were taken at positions $x$ (Days 21,58-61, 63, $73,75-77,80), y(8,15,64)$ and $z(23,67$, $70-72,79)$ 
and gonad development stages (GS). CTD profiles were performed daily from $200 \mathrm{~m}$, and weekly from $1000 \mathrm{~m}$, to the surface. Chlorophyll a concentration (chl a) was measured daily from rosette samples taken at standard depth intervals from $100 \mathrm{~m}$ to the surface (for details see Irigoien et al. 1998).

Classification of gonad maturity. Gonad maturity was determined from preserved females from both WP2 net and multinet hauls. From the multinet hauls up to 50 females from each sample were stained with borax carmine, dehydrated and stored in glycerine. GS was classified according to the classification schema of Niehoff \& Hirche (1996). Young oocytes stain red, whereas oocytes undergoing final maturation stain pink. This method was slightly modified for the females from WP2 net hauls. Due to excellent fixation, their gonad development stage was determined without previous staining using the natural colour of the oocytes as a criterion. Young oocytes appeared opaque, mature oocytes brown. GS1, 2 and 3 describe immature females of increasing maturity; G.S4 characterises mature females ready to spawn. Senescent females were characterised by abnormal oocytes and gaps in the gonads (Niehoff \& Hirche 1996) which have ceased reproductive activity.

Egg production. To determine the egg production rate 50 single females were placed at in situ temperature either in multiwell trays ( $10 \mathrm{ml}$ volume) or in Plexiglas cylinders with net false bottoms suspended in beakers containing $200 \mathrm{ml}$ seawater to separate females and eggs. In the multiwells, eggs were counted and removed at 4 to $12 \mathrm{~h}$ intervals. Females were removed from the beakers after $24 \mathrm{~h}$ incubation, and the eggs were counted.

Frequently, both multiwells and beakers were used for egg production experiments to test the influence of the experimental set-up on the egg production rate. On the other days only multiwells were used. Runge \& Plourde (1994, 1996) suggested that cannibalism occurs in beakers due to wave movement keeping the eggs in suspension. During our study, only 6 out of 48 parallel experiments showed significant differences between egg production rates (eggs female ${ }^{-1} \mathrm{~d}^{-1}$ ) in multiwells and beakers (ANOVA: $0.05>p>0.005$ ). In these cases, only data from the multiwells were used since we supposed them to be more precise due to small control intervals. Otherwise, we pooled the data from the multiwells and the beakers.

Feeding experiments. Feeding and starvation experiments were conducted on 6 occasions to examine the influence of food on the reproduction of Calanus finmarchicus. In each experiment 50 single females were placed in Plexiglas cylinders suspended in beakers for $5 \mathrm{~d}$ at in situ temperature. One half of the females was kept in filtered seawater ( $0.45 \mu \mathrm{m}$ GFC filters), and the other half was fed with the diatom Thalassiosira weiss-

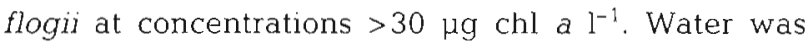
changed daily and egg production checked. At the end of the experiments females were preserved for gonad analysis.

\section{RESULTS}

\section{Hydrography}

Stn $\mathrm{M}$ is situated on the slope of the Norwegian Shelf in the North Atlantic Current. The hydrography is only briefly described here. Details are presented in Irigoien et al. (1998). In the study area, the surface water is of Atlantic origin (Hopkins 1991). According to temperature and salinity measurements, the Atlantic layer mostly extended to $300-400 \mathrm{~m}$ depth and did not reduce to less than $150 \mathrm{~m}$ depth during the investigation period. Intermediate Water of Atlantic and Polar origin (temperature $<3^{\circ} \mathrm{C}$; salinity $<35$ psu) underlay the Atlantic Water at depths between 150 and $700 \mathrm{~m}$. The deep water in this region is formed by Arctic Water (review by Hopkins 1991). According to the hydrography, samples in the upper $100 \mathrm{~m}$ (WP2 net, Rosette, upper multinet samples) were taken in Atlantic Water whereas multinet samples below $250 \mathrm{~m}$ were taken in Intermediate Water, and below $500 \mathrm{~m}$ in Deep Water.

At the beginning of this study, the upper $200 \mathrm{~m}$ was well mixed, with temperatures between 5 and $6^{\circ} \mathrm{C}$. The warming of the surface water to close to $8^{\circ} \mathrm{C}$ at the beginning of May led to stratification at about 30 to $50 \mathrm{~m}$ depth and consequently a phytoplankton bloom developed.

\section{Population development and female maturation}

Considering only $\mathrm{CV}$, males and females, the Calanus finmarchicus population in the upper $100 \mathrm{~m}$ was mainly dominated by females during spring until the end of May (Fig. 2A). During this period the abundance of females varied from 72 to 29069 females $\mathrm{m}^{-2}$, with a median of 2513 females $\mathrm{m}^{-2}$ (Fig. 2B). The mean female size ranged from 2.4 to $2.7 \mathrm{~mm}$ prosome length and remained constant during the study. The proportion of CV varied between 20 and $40 \%$ in March and April. By the end of May, the proportion of CV had increased up to $95 \%$, which was due to both an increase in the abundance of CV and the low abundance of females, with a median of 567 females $\mathrm{m}^{-2}$ (min. 15 and max. 989 females $\mathrm{m}^{-2}$ ). The relative abundance of males reached its maximum in April with over $25 \%$ and decreased to $2-8 \%$ in May and June. Conse- 


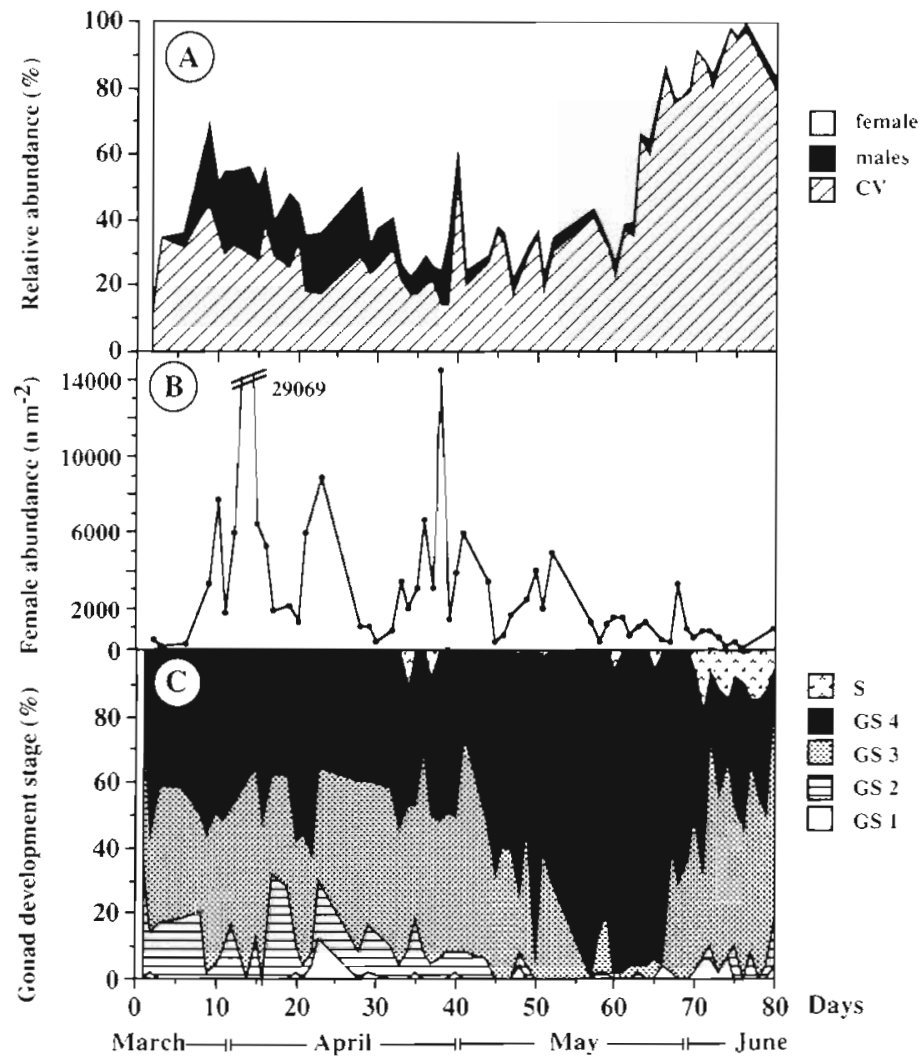

Fig. 2. Calanus finmarchicus. Population development at Stn M during a time series between 22 March and 9 June 1997. (A) Relative abundance of copepodite stage V (CV), males and females (proportion of the total number of CV, males and females). (B) Abundance of females (integrated number of females $\mathrm{m}^{-2}$ in the upper $100 \mathrm{~m}$ of the water column). (C) Gonad development (proportion of total population in GS [gonad stage] 1 to 4 and senescent [S])

quently, the sex ratio (male:female) declined from values exceeding 0.5 to values below 0.05 .

The composition of the female maturation stages was almost constant from the end of March until the beginning of May (Fig. 2C): the proportion of mature females (GS4) varied between 30 and $60 \%$ of females. Females in GS3 contributed an average of $40 \%$. Immature females in GS1 and GS2 were relatively rare, with a maximum of $30 \%$ during the whole investigation period. In May, the proportion of females in GS4 (mature) increased rapidly. From May 17 to 26, mature females dominated with more than $80 \%$; the percentage of GS3 decreased to values of 10 and below, and females in GS1 and 2 were rarely found. At the end of May, the proportion of mature females decreased drastically to values below $40 \%$. At the same time relatively more females in GS3 and senescent females were found. Females in GS1 and GS2 contributed at this time with a maximum of $10 \%$.
Weekly vertical sampling showed that females were concentrated in the upper $50 \mathrm{~m}$ from the end of March to the beginning of May, except in mid April, when the majority $(40 \%)$ was caught between 250 and $100 \mathrm{~m}$ (Fig. 3). On May 17, females were found in equal proportion in the 50 to 0 and 100 to $50 \mathrm{~m}$ depth intervals. At the end of the sampling period (May 25 and 31, June 7), most of the females were found between 50 and $100 \mathrm{~m}$. In depths below $250 \mathrm{~m}$ (Fig. 3) females were absent or very rare. The temporal development of the gonads determined from the multinet samples corresponds to the results from daily WP2 net sampling (compare Figs. $2 \mathrm{C} \& 3$ ). However, there were no significant differences in GS of females from different depth intervals: the proportions of the different development stages (GS 1 to 4, senescent) were similar from $250 \mathrm{~m}$ to the surface. Below $250 \mathrm{~m}$, often too few females were found to determine the proportions of GS. However, sometimes the GS were evenly distributed through the whole water column, and sometimes there was a tendency for proportionately more immature stages in deeper waters.

\section{Reproduction}

According to Irigoien et al. (1998), the investigation period can be divided into 3 periods in relation to phytoplankton development (Fig. 4): (1) During the prebloom period from March until mid May, the chlorophyll a values (integrated over the upper $100 \mathrm{~m}$ ) were low and varied between 16 and $64 \mathrm{mg}$ $\mathrm{m}^{-2}$, with an average of $26 \mathrm{mg} \mathrm{m}^{-2}$. (2) During the phytoplankton bloom (May 10 to 29), the average chlorophyll a concentration was $87 \mathrm{mg} \mathrm{m}^{-2}$, with a maximum $133 \mathrm{mg} \mathrm{m}^{-2}$. (3) During the postbloom (May 30 to June 9), the chl a concentration had decreased to $53 \mathrm{mg} \mathrm{m} \mathrm{m}^{-2}$.

The reproductive parameters, egg production rate, clutch size, proportion of spawning females and proportion of mature females ( $\%$ GS4) were clearly related to phytoplankton development (Fig. 4). From the end of March until the onset of the phytoplankton bloom, the average egg production rate over $49 \mathrm{~d}$ was 8 eggs female $\mathrm{d}^{-1}$ (SD 4 eggs female ${ }^{-1} \mathrm{~d}^{-1}$ ). Mean clutch size was 19 eggs (SD 7 eggs clutch ${ }^{-1}$ ). Clutches $<10$ eggs were relatively frequent (15\%) (Fig. 5). Between 15 and $57 \%$ of the females spawned per day (mean $38 \%$ ), and an average of $47 \%$ of mature females (GS4) was found in the WP2 net samples (Fig. 4). With the onset of the spring bloom in mid May, the daily egg production rate increased up to the maximum of 44 eggs female ${ }^{-1} \mathrm{~d}^{-1}$ measured on May 25. During the whole phytoplankton bloom period (19 d), the mean egg production was 


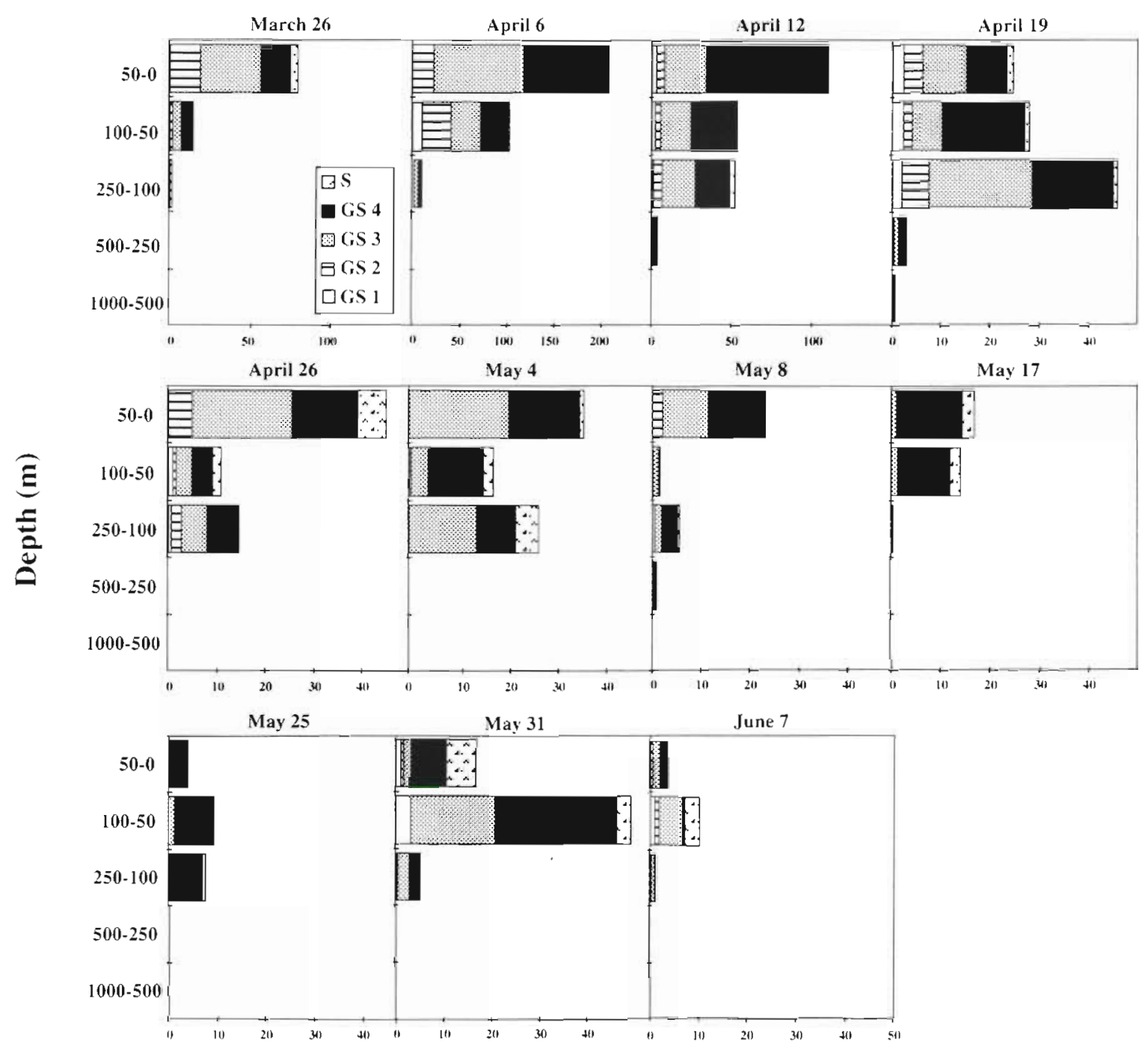

Abundance (Ind. $\mathrm{m}^{-3}$ )

Fig. 3. Calanus finmarchicus. Depth distribution and gonad development stage of females at Stn M between 22 March and 9 June 1997 (number of females $\mathrm{m}^{-3}$ in each depth and each gonad development stage [GS 1 to 4]). S: senescent

24.5 eggs female ${ }^{-1} d^{-1}$ (SD 11 eggs female ${ }^{-1} d^{-1}$ ). Clutch size shifted to higher values; clutches <10 eggs were only rarely found (Fig 5 ). Hence, the mean clutch size increased to 41 eggs (SD 11 eggs clutch-1), with a maximum of 56 eggs (Fig. 4). The average proportion of spawning females reached $56 \%$, varying from $83 \%$ in the middle of the bloom to $30 \%$ at the end. An average of $83 \%$ females in GS4 was found, with a maximum of $100 \%$ on May 18 . With the end of the bloom at the end of May, the reproductive activity of Calanus finmarchicus decreased: egg production rate decreased to an average of 3 eggs female ${ }^{-1} d^{-1}$ (SD 2 eggs female ${ }^{-1} d^{-1}$ ) and mean clutch size to 21 eggs clutch ${ }^{-1}$ (SD 11 eggs clutch ') in the postbloom period. Relatively many clutches of 20 to 30 eggs were found. However, the fre- quency of clutches <10 eggs was low (Fig. 5). Only $12.5 \%$ of the females spawned on average in the first week of June. Correspondingly, just $11 \%$ of the samples were mature females.

Statistical analysis (ANOVA) confirmed that egg production rate and clutch size were significantly higher during the phytoplankton bloom ( $p<0.0001)$. Significant linear relations were found between the reproduction parameters and the chl a concentration but variance was always very high (n of each analysis $=40$; egg production vs chl $a: p<0.0001, \mathrm{R}^{2}=0.422$; clutch size vschl a: $\mathrm{p}<0.0001, \mathrm{R}^{2}=0.513 ; \%$ spawning females vs chl $a: p=0.0041, R^{2}=0.202 ; \%$ GS4 vs chl $a$ : $\left.p<0.0001, R^{2}=0.354\right)$. This was also the case when chlorophyll values from the previous days were used to 


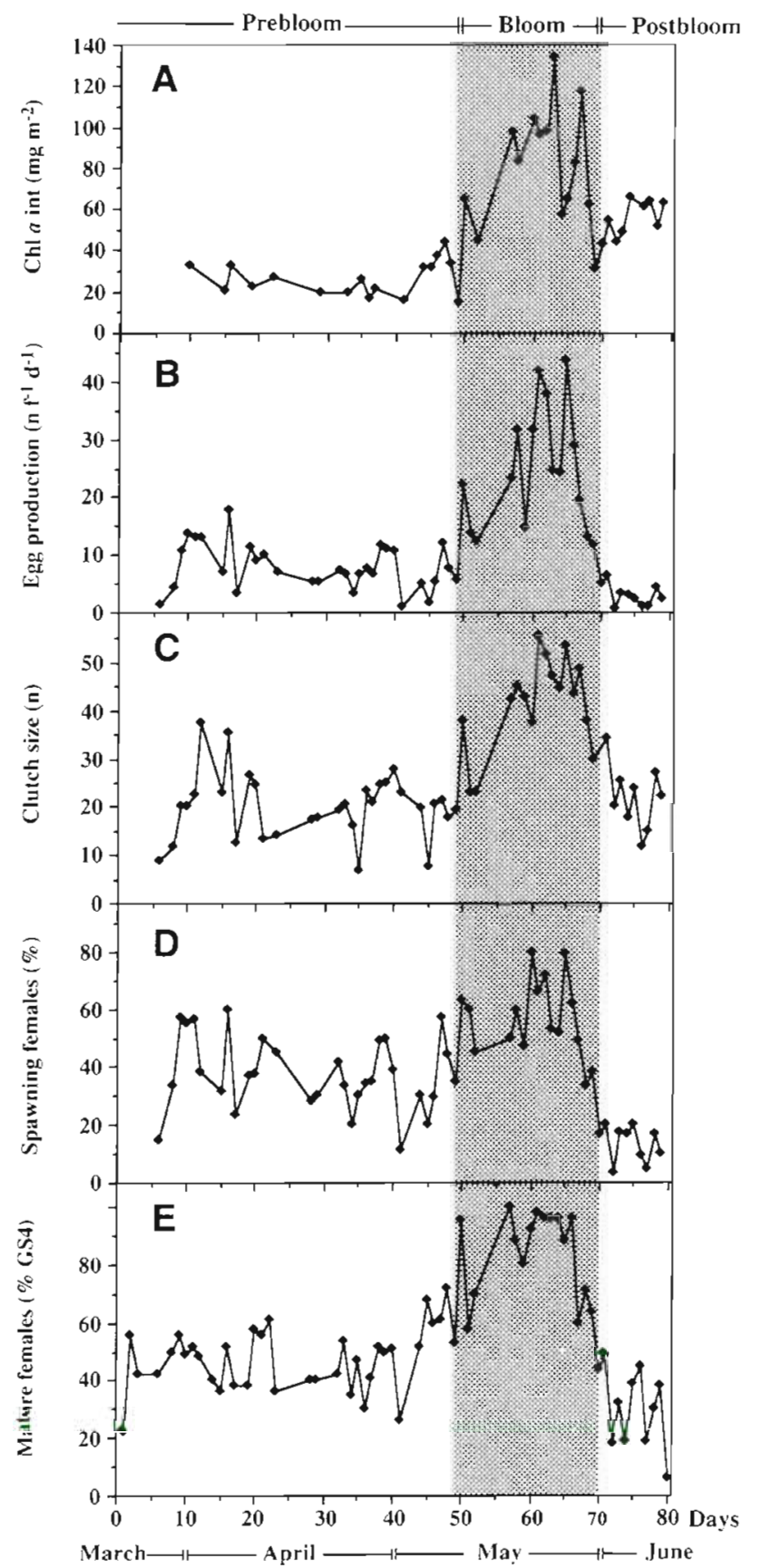

Fig. 4. Calanus finmarchicus. Reproduction at Stn $M$ in relation to phytoplankton development. (A) Integrated total chl a standing stock for the upper $100 \mathrm{~m}$ of the water column. (B) In situ egg production rate. Points represents mean of 50 replicates. (C) Clutch size. Points represent means of 10 to 56 replicates. (D) Proportion of females spawning within $24 \mathrm{~h}$ after capture. (E) Mature females (proportion of total population in GS 4) estimated from preserved samples

consider the response time of reproduction to changes in food availability. Longer time lags were not expected according to experiments by Hirche et al. (1997). When the analysis was performed with data

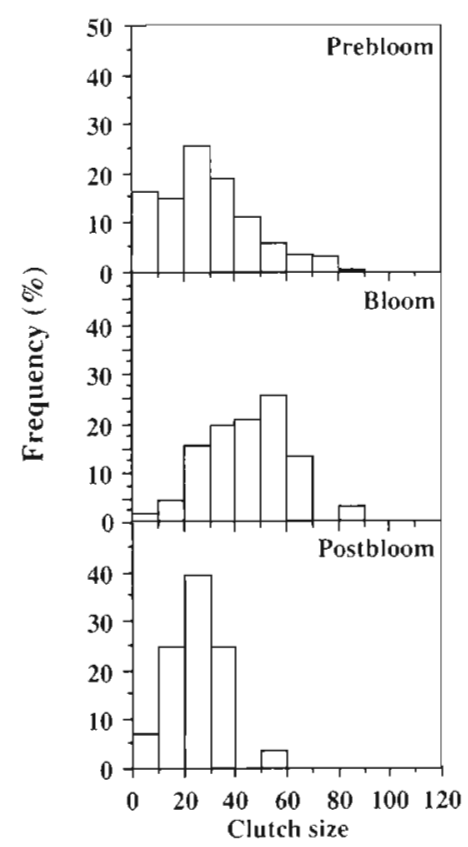

Fig. 5. Calanus finmarchicus. Frequency distribution of clutch size (proportion of the total amount of clutches in each interval) during prebloom, bloom and postbloom at Stn $M$

split up according to prebloom, bloom and postbloom periods, no significant correlation was found between egg production and chlorophyll a concentration in any of the 3 periods. The proportion of spawning females ( $\left.\mathrm{n}=17, \mathrm{p}=0.034, \mathrm{R}^{2}=0.292\right)$ and the proportion of GS4 ( $\mathrm{n}=17, \mathrm{p}=0.002, \mathrm{R}^{2}=0.480$ ) were significantly related to chl a concentration only during the prebloom while clutch size versus chl a was significant only during the bloom ( $\mathrm{n}=14, \mathrm{p}=0.027, \mathrm{R}^{2}=0.345$ ).

\section{Feeding experiments}

As typical examples of the prebloom, bloom and postbloom situations, 3 out of 6 experiments are presented here in detail, to demonstrate the influence of feeding and starvation on reproduction in relation to in situ feeding conditions. The results of the other experiments (23 April, 4 May and 23 May) show the same response of egg production to experimental conditions.

During the prebloom period, on April 28 the in situ egg production rate was 12 eggs female ${ }^{-1} d^{-1}$ (SD 13 eggs female $\mathrm{d}^{-1}$ ), about half of the females were mature (GS4; Fig. 6A). After 5 d of feeding, egg production rate increased to 48 eggs female $\mathrm{f}^{-1} \mathrm{~d}^{-1}$ (SD 30 eggs female ${ }^{-1} \mathrm{~d}^{-1}$ ). During this period, the percentage of mature females increased. Non-fed females stopped egg production within $2 \mathrm{~d}$ and less than $10 \%$ remained mature. 


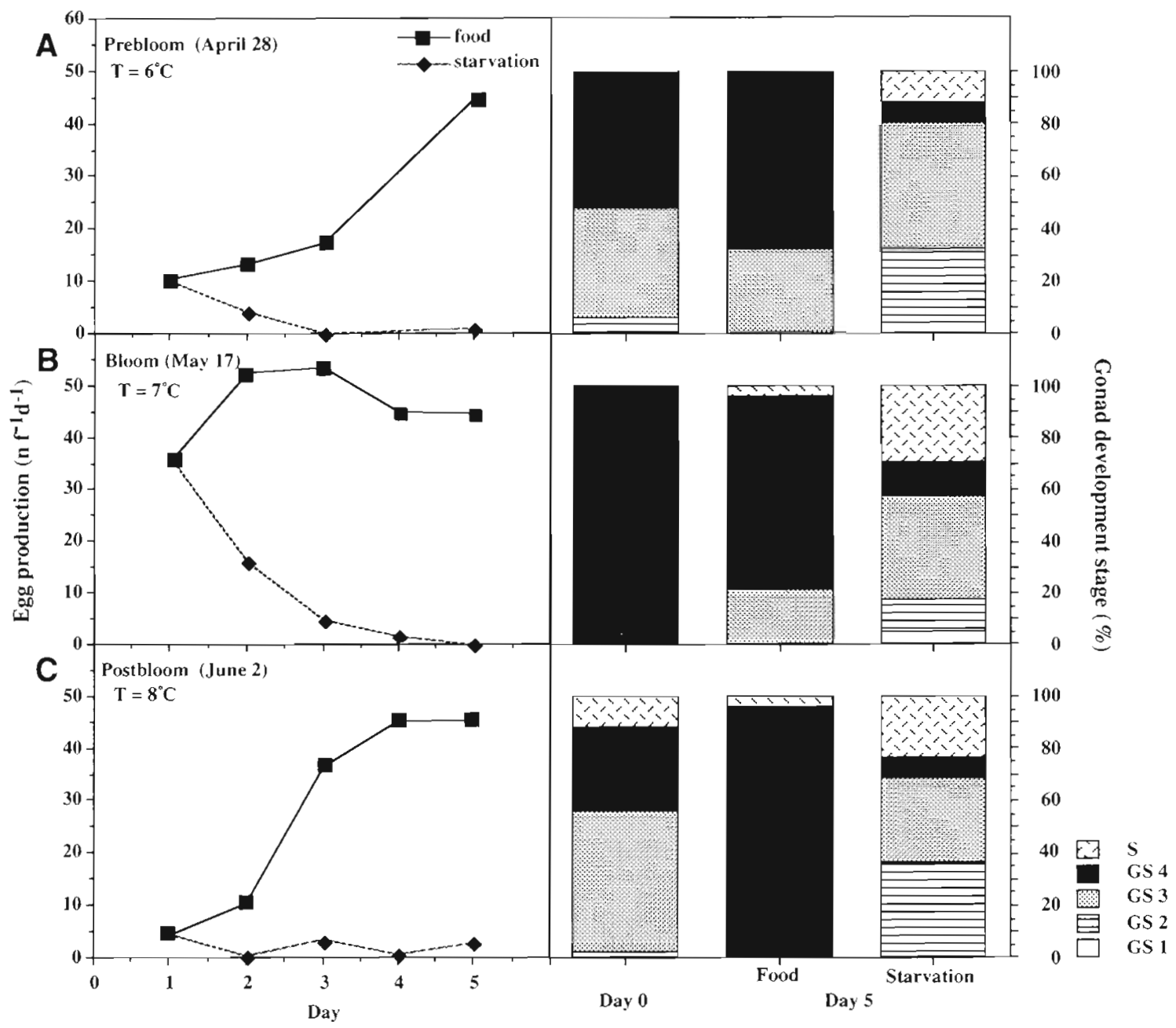

Fig. 6. Calanus finmarchicus. Comparison of egg production and gonad development of fed and non-fed females estimated in laboratory experiments during prebloom, bloom and postbloom. Females were kept at in situ temperature (given in left-hand panels)

In females sampled during the bloom on May 17 (in situ egg production rate 35 eggs female f $^{-1} \mathrm{~d}^{-1}, \mathrm{SD}$ 27 eggs female $\mathrm{e}^{-1}$; GS $4100 \%$ ), the egg production rate increased to 50 eggs female ${ }^{-1} \mathrm{~d}^{-1}$ (SD 29 eggs female $\mathrm{f}^{-1} \mathrm{~d}^{-1}$ ) after $5 \mathrm{~d}$ of feeding; $75 \%$ of the females were found to be in GS4 after $5 \mathrm{~d}$ (Fig. 6B). Under starvation conditions, the egg production decreased dramatically within $2 \mathrm{~d}$ to 15 eggs female $\mathrm{e}^{-1} \mathrm{~d}^{-1}$ (SD 16 eggs female $\mathrm{d}^{-1} \mathrm{~d}^{-1}$ ) and finally ceased on Day 5 . Correspondingly, just $12 \%$ of the females were in GS4, 35\% were senescent, and the rest were immature.

Females collected during the postbloom period on June 2 were mainly in GS3, only $35 \%$ were in GS4. The in situ egg production rate was 3 eggs female $\mathrm{e}^{-1} \mathrm{~d}^{-1}$ (SD 7 eggs female ${ }^{-1} \mathrm{~d}^{-1}$ ). After $5 \mathrm{~d}$ of feeding the egg production rate increased to 45 eggs female $\mathrm{d}^{-1}$ (SD 28 eggs female $\mathrm{d}^{-1}$ ), and $95 \%$ of the females were in GS4 (Fig. 6C). In starved females the egg production rate remained as low as the in situ rate. The proportion of mature females had decreased and more senescent females and females in GS2 were found.

\section{DISCUSSION}

\section{Reproductive cycle of Calanus finmarchicus}

The reproductive cycle of Calanus finmarchicus in the Atlantic Water of the Norwegian Sea followed 3 periods of phytoplankton development: (1) the prebloom with relatively low egg production rates, (2) the bloom with high egg production rates, and (3) the postbloom with egg production close to zero. This agrees with the prevailing knowledge of the close relationship between the reproduction of C. finmarchicus and the phytoplankton concentration (e.g. Marshall \& Orr 
Table 1. Comparison of 3 time series focusing on the reproduction of Calanus finmarchicus. Egg production rates (eggs female ${ }^{-1}$ $\mathrm{d}^{-1}$ ) and clutch sizes (eggs clutch ${ }^{-1}$ ) are given as means of the population

\begin{tabular}{|c|c|c|c|}
\hline & $\begin{array}{l}\text { Lower estuary of St. Lawrence } \\
\text { (Canada) (Plourde \& Runge 1993) }\end{array}$ & $\begin{array}{c}\text { Yalangenfjord } \\
\text { (Norway) (Diel \& Tande 1992) }\end{array}$ & $\begin{array}{c}\text { Weathership Stn M } \\
\text { (Norwegian Sea) (this study) }\end{array}$ \\
\hline Study period & April $18-$ August 26 & March 14-May 2 & March 26-June 8 \\
\hline Reproductive period & Mid June-end of August & End of March-beginning of May & March (?)-end of May \\
\hline Duration & ca 12 wk & $\mathrm{ca} 6 \mathrm{wk}$ & $>10 w k$ \\
\hline Main reproduction month & July & April & May \\
\hline Temperature range $\left({ }^{\circ} \mathrm{C}\right)$ & $4-9$ & $3-5$ & $5.5-9$ \\
\hline \multicolumn{4}{|l|}{ Eggs female $\mathrm{e}^{-1} \mathrm{~d}^{-1}$} \\
\hline Before bloom & $<10(8 w k)^{d}$ & $<10(2 w k)^{b}$ & $3-18(6 w k)$ \\
\hline During bloom & $22-82(9 w k)^{a}$ & $20-33(2-3 w k\}^{b}$ & $14-44(3 w \mathrm{k})$ \\
\hline After bloom & $30-50(2 w k)^{a}$ & $5-10(1 w k)^{b}$ & $1-5(2 w k)$ \\
\hline Eggs clutch $^{-1}$ & Range $=70-120$ & Max. $=70$ & $\operatorname{Max}=56$ \\
\hline Prosome length (mm) & $2.9-3.1$ & 2.6 & 2.6 \\
\hline
\end{tabular}

1955, Runge 1985, Hirche 1996 and references therein, Hirche et al. 1997) and also the results from previous time series (see Table 1).

Considerable differences exist in the temporal development of the reproductive activity of Calanus finmarchicus between the Norwegian Sea, North Norwegian fjords and the lower estuary of the Gulf of St. Lawrence (Table 1) which are apparently due to the local development of the phytoplankton. In these areas different hydrographical and latitudinal factors control phytoplankton development. In the Norwegian Sea the phytoplankton bloom does not develop before mid May (Halldal 1953, Dale 1995, Irigoien et al. 1998), when warming of the surface water leads to stratification. In the North Norwegian fjords, the spring bloom is driven by the light regime and starts earlier, usually in mid April (Eilertsen \& Taasen 1984). In contrast, in the Gulf of St. Lawrence the phytoplankton bloom starts in mid June and persists usualiy until September (Plourde \& Runge 1993, and references therein). Consequently, the spawning activity of $C$. finmarchicus starts in different months and has a variable duration.

Prior to the spring bloom, mature gonads and spawning activity have been observed occasionally by several authors (Sømme 1934, Marshall \& Orr 1955, Davis 1976, Tande \& Hopkins 1981). At Stn $M$, however, more than $50 \%$ of female Calanus finmarchicus were mature and maintained low egg production over a period of more than $9 \mathrm{wk}$. In contrast, in the Gulf of St. Lawrence, Plourde \& Runge (1993) found only a few mature females and no egg production for $6 \mathrm{wk}$ during the prebloom, whereas the period of low egg production $\left(<10\right.$ eggs female $\left.{ }^{-1} \mathrm{~d}^{-1}\right)$ lasted for $2 \mathrm{wk}$ only. In the North Norwegian fjords, the prebloom period was short since the phytoplankton bloom occurred shortly after the females had developed from CV (Tande 1982, Diel \& Tande 1992). During the prebloom period at Stn $M$, egg production was strongly food limited, as shown during the feeding and starvation experiments (Fig. 6). Irigoien et al. (1998) suggested that internal lipid reserves were also used for reproduction as ingestion of phytoplankton was not sufficient to cover the costs of egg production. However, the experiments indicate that the food was essential for gonad maturation and egg production of $C$. finmarchicus and that no eggs are produced from internal reserves alone. This is in accordance with earlier experiments (e.g. Hirche et al. 1997)

Suboptimal production was observed at Stn M during the bloom as well. The maximum egg production rate in this period differed only slightly from that in the Malangenfjord, although temperature at Stn $M$ was about $4^{\circ} \mathrm{C}$ higher (Table 1). Since the females had the same size at both locations (Table 1), we expected higher rates at the warmer Stn $M$. The maximum rate reported by Plourde \& Runge (1993, see Table 1) is in the range of the egg production rate of $73 \mathrm{egg} \mathrm{female}^{-1}$ $\mathrm{d}^{-1}$ at $8^{\circ} \mathrm{C}$ with surplus food measured in laboratory experiments by Hirche et al. (1997). Since these 2 studies were conducted with larger females (Plourde \& Runge: see Table 1 , Hirche et al.: mean ca 2.8, range $2.7-3.0 \mathrm{~mm}$ (unpubl. data]), the higher maximum rates could be due to female size.

The decrease of egg production and clutch size during postbloom at Stn M matches earlier observations in the Malangenfjord (Diel \& Tande 1992). In contrast. significant postbloom reproduction, based mostly on. microzooplankton, has been described for the Gulf of St. Lawrence (Ohman \& Runge 1994, Runge \& Plourde 1996) 
According to our hydrographic data, the results described here represent the reproductive cycle of Calanus finmarchicus in the Atlantic Water masses of the North Atlantic Current (NAC), as all of the measurements in the upper $100 \mathrm{~m}$ were carried out in Atlantic Waters (Irigoien et al. 1998). Stn M is situated in the central part of a large eddy, where the renewing of the water masses takes place very slowly (Halldal 1953). There was no indication of tongues of coastal water advecting phytoplankton and zooplankton populations from the Norwegian shelf, which was observed during earlier time series studies (Dale 1995). Due to its close relationship with food availability, the reproductive biology of $C$. finmarchicus should strongly react to regional variability in phytoplankton development. In the Norwegian Sea both longitudinal and latitudinal gradients were noted. Phytoplankton development starts in March along the Norwegian coast, where the salinity range maintains stratification throughout the year (Rey 1981). In contrast, in the open ocean bloom development depends on heating of the surface layers and takes place much later. Accordingly, Niehoff \& Hirche (1997) registered maximum reproductive activity of $C$. finmarchicus 2 mo earlier than at Stn M. Within the NAC the bloom occurred in the southern part at about $62^{\circ} \mathrm{N} 2$ or $3 \mathrm{wk}$ earlier than in the northern part at about $69^{\circ} \mathrm{N}$ (Braarud et al. 1958). This delay towards the north should also affect the reproductive cycle.

\section{Food supply and egg production}

The importance of food supply for the reproductive cycle of Calanus finmarchicus at $\operatorname{Stn} M$ is also supported by the significant relation of ingestion rate and egg production (Irigoien et al. 1998). However, high variance of the correlation between chl a concentration and egg production rate suggests that the chl a concentration is not an ideal parameter for predicting egg production. The significant correlation is presumably due to the large differences between prebloom and bloom values. When data were split up into prebloom, bloom and postbloom periods, no significant correlations were found between the egg production rate and chl a. Plourde \& Runge (1993) found no significant correlation either, once the phytoplankton bloom had started in the Gulf of the St. Lawrence. However, at Stn $M$ other reproductive parameters were significantly affected by food concentration in different periods: during prebloom, the proportion of both mature (GS4) and spawning females was correlated with chl $a_{\text {, }}$ whereas during the bloom clutch size was related to food concentration. This leads to the hypothesis that the increase of the mean egg production of a popula- tion due to increasing food supply occurs stepwise due to (1) an increase of mature females at low food concentration and (2) an increase of clutch size when most females are mature. If this holds true, it might help to explain why chl a is such a poor indicator for egg production rate. Other possible explanations include the patchy distribution of chlorophyll in the water column and the fact that it does not cover heterotrophic microorganisms which can provide an important food resource for reproduction (Ohman \& Runge 1994). During our study in the Norwegian Sea the microzooplankton abundance was very low and contributed only a few percent to the food of $C$. finmarchicus (Irigoien et al. 1998).

Apart from food concentration, food quality is important for reproductive success of Calanus finmarchicus (e.g. Marshall \& Orr 1955, Runge \& Plourde 1996, Ban et al. 1997). Factors such as particle size and species composition influence feeding (for review see Harris 1996). In addition, algal species might have different nutritional values. Thus Runge \& Plourde (1996) suggested that dinoflagellates might be more nutritious than diatoms. At Stn $M$, the cell size and composition of the phytoplankton, and thus the food quality, changed considerably. C. finmarchicus feeds on particles $>5 \mu \mathrm{m}$ (Frost 1972). The contribution of this size fraction to the total phytoplankton stock was below $20 \%$ during the prebloom, increased up to $80 \%$ during the bloom, and decreased again after the bloom to below $20 \%$ (Irigoien et al. 1998). Egg production rate was significantly correlated with the concentration of this size fraction (ANOVA, $p=0.0001$ ), with considerably lower variance $\left(\mathrm{R}^{2}=0.823\right)$ compared to the correlation between egg production rate and total phytoplankton stock $\left(R^{2}=0.577\right)$. The prebloom community was dominated by green algae and prymnesiophytes, the bloom by diatoms, and the postbloom by cryptophytes and again prynmesiophytes (Irigoien et al. 1998). MeyerHarms et al. (1999) observed an evident preference for dinoflagellates during the prebloom, and for diatoms (mainly Rhizosolenisa spp.) during the bloom. Statistical analysis shows significant correlations between egg production and concentrations of dinoflagellates and diatoms (Table 2). However, dinoflagellates were found only at low concentrations ( 2 to $3 \%$ of the chl a) at Stn M, while diatoms contributed up to $33 \%$ during the bloom and constituted an important food component of C. finmarchicus (Meyer-Harms et al. 1999). A reduction of egg production rate by diatoms, as discussed recently (Ianora et al. 1995, Ban et al. 1997) could not be proven in this study.

In the postbloom period, low egg production rates were observed, although the phytoplankton concentration in the water column was relatively high, and the ingestion of phytoplankton carbon exceeded the 
Table 2. Statistical analysis (linear regression, ANOVA) of the correlation between the egg production rate of Calanus finmarchicus and the concentration of different algal species (data of pigment concentration from Irigoien et al. 1998) during a time series at Stn M (Norwegian Sea)

\begin{tabular}{|lcc|}
\hline Egg production versus & $\mathrm{p}$ & $\mathrm{R}^{2}$ \\
\hline Dinoflagellates & 0.003 & 0.601 \\
Diatoms & 0.042 & 0.352 \\
Chlorophycea & 0.051 & 0.328 \\
Cryptophycea & 0.133 & 0.211 \\
Cyanophycea & 0.261 & 0.124 \\
Chrysophycea & 0.542 & 0.038 \\
Prymnesiophytes & 0.938 & 0.0062 \\
\hline
\end{tabular}

costs for egg production (Irigoien et al. 1998). Food quality presumably limited egg production during the postbloom period when prymnesiophytes, mainly Phaeocystis pouchetii, dominated the phytoplankton stock (Meyer-Harms et al. 1999) since females fed in the laboratory during postbloom matured and commenced spawning. This indicates that no internal regulation reduced egg production after the bloom as suggested by Diel \& Tande (1992). Recent field studies (Plourde \& Runge 1993, this study) and laboratory observations (Hirche 1990, Niehoff unpubl. data) have shown that the duration of the reproductive period of Calanus finmarchicus is extremely variable and depends on food conditions rather than on genetic determination.

\section{Reproductive strategy of Calanus finmarchicus}

The capability of Calanus finmarchicus to mature and to maintain egg production at low food concentrations enhances the adaptation to a highly variable environment in the following ways:

(1) The final maturation processes with respect to metabolic pathways, including the processes of vitellogenesis 1 and 2 and maturation division (Niehoff \& Hirche 1996), are established and enable the females to rapidly respond to either sudden local food maxima or to developing phytoplankton blooms. Thus, in feeding experiments during prebloom, egg production increased after $3 \mathrm{~d}$. The high frequency sampling during our study shows that Calanus finmarchicus reacted immediately to the spring bloom. Runge \& Plourde (1996) described a time lag of $8 \mathrm{~d}$ between the onset of the phytoplankton bloom and the increase of egg production from zero to maximum values, and suggested that this time was needed for oocyte maturation. In the Gulf of St. Lawrence, the majority of these females was immature during the prebloom period (Plourde \& Runge 1993), indicating that the food supply was not sufficient for maturation and thus causing a longer lag phase compared to Stn $\mathrm{M}$.

(2) Egg production during the prebloom extends the reproductive period of Calanus finmarchicus considerably. Thus, at Stn $M$ it was more than twice as long as in North Norwegian fjords (Tande 1982, Diel \& Tande 1992). It is also important to point out that due to the high abundance of females during the prebloom period, the egg production of the population was high in spite of low individual egg production rates (Fig. 7). During the prebloom period, C. finmarchicus females produced on average 34187 eggs $\mathrm{m}^{-2} \mathrm{~d}^{-1}$, which is as high as during the bloom (34855 eggs $\mathrm{m}^{-2} \mathrm{~d}^{-1}$ ). Assuming an egg carbon content of $0.23 \mu \mathrm{g}$ (Ohman \& Runge 1994), the secondary production of the females is $7.86 \mathrm{mg}$ carbon $\mathrm{m}^{-2} \mathrm{~d}^{-1}$. Since the prebloom was more than twice as long as the bloom period, more eggs were actually produced when phytoplankton was rare than during the period of high reproductive activity during the bloom.

The decoupling of the reproduction of Calanus finmarchicus from the phytoplankton bloom may enhance the chance for reproductive success of the population. The relevance of early production for the population has to be revealed by data on abundance of nauplii and young copepodites giving information on hatching, recruitment success and mortality. However, eggs and nauplii of $C$. finmarchicus are known to be an important food resource for fish larvae (e.g. Runge 1988, Lough \& Mountain 1996). Hence, the high secondary production by $C$. finmarchicus could provide food for the larvae of the herring (Hardy 1924, cited in Raymont 1983) migrating through this area (Misund et al. 1997) months before the phytoplankton bloom starts.

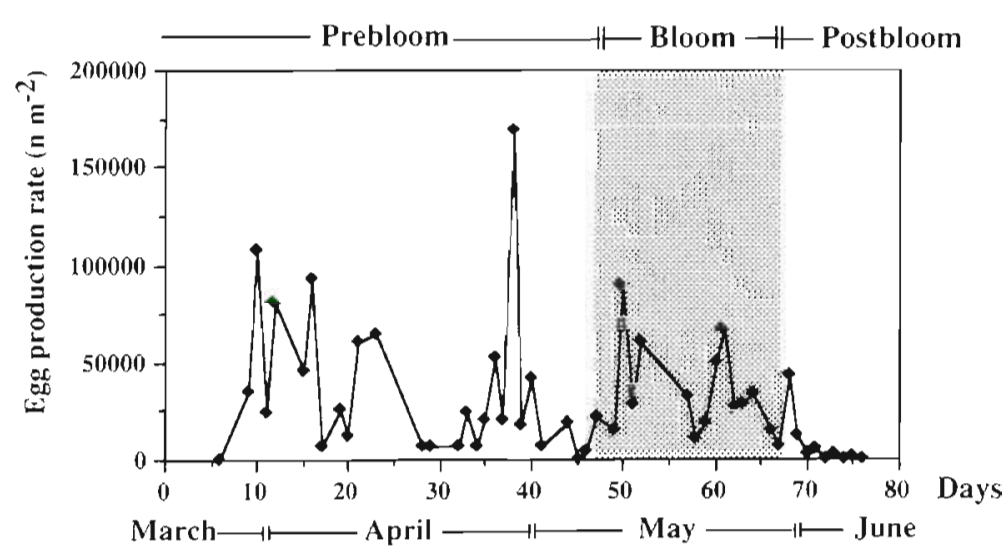

Fig. 7 Calanus finmarchicus. Egg production rate of the population during the time series between 22 March and 9 June 1997 
Acknowledgements. We thank the Captain and the crew of the weathership 'Polarfront' for their support. Thanks are also due to Bjornar Ellertsen for his excellent help organising this project as well as to Hein-Runge Skjoldal at the Institute for Marine Research in Bergen for his collaboration. This study was supported by funding from the European Commission through the TASC project. Contract MAS3-CT95-0039. This is publication no. 1527 of the Alfred-Wegener-Institute for Polar and Marine Research, Bremerhaven.

\section{LITERATURE CITED}

Ban S, Burns C, Castel J, Chaudron Y, Christou E, Escribano $R$, Fonda Umani $S$, Gasparini $S$, Guerrero Ruiz $F$, Hoffmeyer $M$, lanora $A$, Kang $H K$, Laabir $M$, Lacoste $A$, Miralto A, Ning X, Poulet S, Rodriguez V, Runge J, Shi J, Starr M, Uye S, Wang Y (1997) The paradox of diatomcopepod interactions. Mar Ecol Prog Ser 157:287-293

Braarud TK, Ringdal G, Nordli O (1958) Seasonal changes in the phytoplankton at various points of the Norwegian west coast. Fiskeridir Skr Ser Havunders 12:1-77

Dale T (1995) Planteplanktonets sesongutvilding på Stasjon $\mathrm{M}$ in årene 1990-1992. Thesis, University of Bergen

Davis CC (1976) Overwintering strategies of common planktic copepods in some North Norway fjords and sounds. Astarte 9:37-42

Diel S, Tande K (1992) Does the spawning of Calanus finmarchicus in high latitudes follow a reproducible pattern? Mar Biol 113:21-31

Eilertsen HC. Taasen TP (1984) Investigations on the phytoplankton community of Balsfjorden, northern Norway. The phytoplankton 1976-1978. Environmental factors, dynamics of growth, and primary production. Sarsia 69 : $1-15$

Frost BW (1972) Effects of size and concentration of food particles on feeding behaviour of the marine planktonic copepod Calanus pacificus. Limnol Oceanogr 17:805-815

Halldal P (1953) Phytoplankton investigations from Weathership $M$ in the Norwegian Sea, 1948-1949. Hvalraddets Skr $38: 1-91$

Harris R (1996) Feeding ecology of Calanus. Ophelia 44 $85-109$

Hirche HJ (1990) Egg production of Calanus finmarchicus at low temperature. Mar Biol 106:53-58

Hirche HJ (1996) The reproductive biology of the marine copepod Calanus finmarchicus-a review. Ophelia 44: $111-128$

Hirche HJ, Meyer U, Niehoff B (1997) Egg production of Calanus finmarchicus-effect of food, temperature and season. Mar Biol 127:609-620

Hopkins TS (1991) The GIN-Sea - a synthesis of its physical oceanography and literature review 1972-1985. Earth-Sci Rev 30:175-318

Ianora A, Poulet SA, Miralto A (1995) A comparative study of the inhibitory effect of diatoms and the reproductive biology of the copepod Temora stylifera. Mar Biol 121. $533-539$

Irigoien X, Head R, Klenke U, Meyer-Harms B, Harbour D, Niehoff B, Hirche HJ, Harris R (1998) A high frequency time series at Weathership $M$, Norwegian Sea, during the 1997 spring bloom: feeding of adult female Calanus finmarchicus. Mar Ecol Prog Ser 172:127-137

Lough RG, Mountain DG (1996) Effect of small-scale turbulance on feeding rates of larval cod and haddock in stratified water on Georges Bank. Deep-Sea Res II 43(7/8): $1745-1772$
Marshall SM, Orr AP (1953) Calanus finmarchicus: egg production and egg development in Tromso Sound in spring. Acta Borealia (A) Sci 5:3-19

Marshall SM, Orr AP (1955) The biology of a marine copepod Calanus finmarchicus Gunnerus. Oliver and Boyd, Edinburgh

McLaren I, Leonard A (1995) Assessing the equivalence of growth and egg production of copepods. ICES $J$ Mar Sci $52: 397-408$

Meyer-Harms B, Irigoien X, Head R, Harris R (1999) Selective feeding on natural phytoplankton by Calanus finmarchicus before, during and after the 1997 spring bloom in the Norwegian Sea. Limnol Oceanogr 44(1): in press

Misund OA, Melle W, Fernö A (1997) Migration behaviour of Norwegian spring spawning herring when entering the cold front in the Norwegian Sea. Sarsia 87:107-112

Niehoff B, Hirche HJ (1996) Oogenesis and gonad maturation in the copepod Calanus finmarchicus and the prediction of egg production from preserved samples. Polar Biol 16: $601-612$

Niehoff B, Hirche HJ (1997) The reproduction of Calanus finmarchicus in the Norwegian Sea in spring. ICES CM 1997/T52

Ohman MD, Runge JA (1994) Sustained fecundity when phytoplankton resources are in short supply; omnivory by Calanus finmarchicus in the Gulf of St. Lawrence. Limnol Oceanogr 1:21-36

Østvedt OJ (1955) Zooplankton investigations from Weathership $M$ in the Norwegian Sea, 1948-1949. Hvalrådets Skr 40:1-93

Plourde S, Runge JA (1993) Reproduction of the planktonic copepod Calanus finmarchicus in the Lower St. Lawrence Estuary: relation to the cycle of phytoplankton production and evidence for a Calanus pump. Mar Ecol Prog Ser 102: $217-227$

Poulet S, Ianora A, Laabir M, Klein Breteler WCM (1995) Towards the measurement of secondary production and recruitment in copepods. ICES J Mar Sci 52:359-368

Raymont $J$ (1983) Plankton and productivity in the oceans, 2nd edn, Vol 2, Zooplankton. Pergamon Press, Oxford

Rey F (1981) The development of the spring phytoplankton outburst at selected sites off the Norwegian coast. In: Sætre R, Mork M (eds) Proc Norwegian Coastal Current Symp, September 1980. University of Bergen. Bergen, p 649-680

Runge JA (1985) Egg production rates of Calanus finmarchicus in the sea off Nova Scotia. Arch Hydrobiol Beih 21: $33-40$

Runge JA (1988) Should we expect a relationship between primary production and fisheries? The role of copepod dynamics as a filter of trophic variability. Hydrobiologia 167/168:61-71

Runge JA, Plourde S (1994) Sources of error in the measurement of egg production rates of the planktonic copepod, Calanus finmarchicus. EOS 75:187

Runge JA, Plourde S (1996) Fecundity characteristics of Calanus finmarchicus in coastal waters of eastern Canada. Ophelia 44:171-187

Skjoldal HR, Rey F (1989) Pelagic production and variability of the Barents Sea ecosystem. In: Sherman A, Alexander LM (eds) Biomass yields and geography of large marine ecosystems. Westview Press, AAAS Selected Symposium 111. Boulder, CO, p 241-286

Skjoldal HR, Hassel A, Rey F, Loeng H (1987) Spring phytoplankton development and zooplankton reproduction in the central Barents Sea in the period 1979-1984. In: Loeng $\mathrm{H}$ (ed) The effect of oceanographic conditions on distribu- 
tion and population dynamics of commercial fish stocks in the Barents Sea. Proc 3rd Soviet-Norwegian Symp, Murmansk, 26-28 May. Institute for Marine Research, Bergen, p $59-89$

Smith SL (1990) Egg production and feeding by copepods prior to the spring bloom of phytoplankton in Fram Strait. Greenland Sea. Mar Biol 106:59-69

Semme JD (1934) Animal plankton of the Norwegian Coast waters and the open sea: I. Production of Calanus finmarchicus (Gunnerus) and Calanus hyperboreus (Kroyer) in the Lofoten area. Rep Norw Fish Invest 4(9):1-163

Editorial responsibility: Otto Kinne (Editor),

Oldendorf/Luhe, Germany
Tande KS (1982) Ecological investigations on the zooplankton community of Balsfjorden, northern Norway: generation cycles and variation in body weight and body content of carbon and nitrogen related to overwintering and reproduction in the copepod Calanus finmarchicus. J Exp Mar Biol Ecol 62:129-142

Tande KS, Hopkins CCE (1981) Ecological investigations of the zooplankton community of Balsfjorden, northern Norway: the genital biological system in Calanus finmarchicus and the role of gonad development in overwintering strategy. Mar Biol 63:159-164

Submitted: May 12, 1998; Accepted: September 17, 1998 Proofs received from author(s): December 14, 1998 